\title{
Pterygium: prevalence and severity in an Amazonian ophthalmic setting, Brazil
}

\author{
Pterígio: prevalência e gravidade em um cenário \\ oftálmico na Amazônia, Brasil
}

Sophie Joanna Coutts ${ }^{1}$, Andrew Coombes ${ }^{2}$

\begin{abstract}
Objective: This is a cross sectional ophthalmic clinic-based study to estimate the prevalence and severity of pterygium in a selected population in the Amazon Basin, Brazil. Methods: The study included 225 subjects above 20 years age from three different places of residence of Manaus city (group 1, $n=89$ ), river based communities (group 2, $n=116$ ) and indigenous rainforest inhabitants (group 3, $n=20)$. Pterygia was graded 1-4 by torch examination and gender, age and occupation determined. Results: were assessed to have pterygia (grades 2-4) 117 people; 52\% against 108 control subjects with bilateral disease in $43 \%$ of subjects. Prevalence of grades $2-4$ increased from $36 \%$ in group 1 to $62.5 \%$ in group 2 and $75 \%$ in group 3. Of these subjects the percentage with outdoor professions increased across the groups from $31.2 \%$ to $67.1 \%$ and $70 \%$ respectively. Also subjects of group 2 who worked largely outdoors, showed increasing pterygia severity, from grades 2 at $57 \%$ ( $p=0.0002)$, grade 3 at 93.3\% ( $p, 0.0001)$ to grade 4 at $100 \%(p=0.0004$ Conclusion: Amazonian communities have a high prevalence of pterygia, which correlates to greater outdoor occupation and sun exposure. This study agrees with previous worldwide reports and it is the first study to compare the prevalence of pterygium in rural and urban living in Amazonian in Brazil. This study highlights the public health significance and gross need for intervention studies.
\end{abstract}

Keywords: Pterygium/epidemiology; Prevalence; Public health; Severity of illness index; Sunlight

\begin{abstract}
RESUMO
Objetivo: Este é um estudo clínico oftálmico transversal para estimar a prevalência e gravidade de pterígios em uma população específica na bacia Amazônica, Brasil. Métodos: O estudo incluiu 225 indivíduos acima de 20 anos de idade, oriundos de três diferentes residências na cidade de Manaus (grupo $1, \mathrm{n}=89$ ), comunidades ribeirinhas (grupo 2, $\mathrm{n}=116$ ) e indígenas que habitam nas florestas (grupo 3, $\mathrm{n}=20$ ). Pterígios foram classificados de 1-4 pelo exame com tocha e determinando-se sexo, idade e ocupação. Resultados: Foram diagnosticadas 117 pessoas com pterígio (graus 2-4); 52\% contra 108 indivíduos com doença bilateral em $43 \%$ dos indivíduos. Prevalência de graus 2-4 aumentou de 36\% no grupo 1 para $62,5 \%$ no grupo 2 e $75 \%$ no grupo 3 . Dentre estes indivíduos, o percentual com profissões ao ar livre aumentou entre os grupos para 31,2\%, 67,1\% e 70\%, respectivamente. Além disso, indivíduos do grupo 2 que trabalhavam em grande parte ao ar livre, mostrou aumento da gravidade do pterígio, com grau 2 a $57 \%$ ( $\mathrm{p}=0.0002$ ), grau 3 a 93.3\% (p,0.0001) e grau 4 a 100\% (p=0.0004). Conclusão: Comunidades amazônicas têm uma alta prevalência de pterígios, que se correlaciona com maior ocupação ao ar livre e exposição ao sol. Este estudo concorda com relatórios anteriores em todo o mundo e é o primeiro estudo a comparar a prevalência de pterígio nas zonas rural e urbana da Amazônia no Brasil. Este estudo destaca a importância da saúde pública e a necessidade de estudos de intervenção.
\end{abstract}

Descritores: Pterígio/epidemiologia; Prevalência; Saúde pública; Índice de gravidade da doença; Luz solar

\footnotetext{
${ }^{1}$ Broomfield Hospital, Mid Essex Hospitals NHS Trust, Chelmsford, Essex, United Kingdom;

${ }^{2}$ St Bartholomews' \& The Royal London University NHS Hospital Trust, London, United Kingdom.
}

Conflict-of-interest disclosure : None of the authors have any proprietary interests or conflicts of interest related to this submission. The work received research funding from the The Wellcome Trust and The Worshipful Company of Barbers, London.

Recebido para publicação em: 2/9/2011 - Aceito para publicação em: 27/5/2012

Rev Bras Oftalmol. 2012; 71 (6): 372-6 


\section{INTRODUCTION}

$\mathbf{W}$ orldwide studies associate risk factors such as ultraviolet sunlight exposure, dry climatic conditions and genetics with the development of pterygia ${ }^{(1-5)}$. Usually pterygia are small and asymptomatic conjunctival 'wing - shaped' extensions on to the cornea, but when large may produce discomfort, poor cosmetic appearance and loss of visual acuity, which requires surgery to correct ${ }^{(6,7)}$.

The aim of this project was to determine and compare the severity and prevalence of pterygia within three different population groups in an ophthalmic clinic setting based on location within the Amazon basin, Brazil.

\section{Methods}

A random observational cross sectional study of 225 subjects was carried out within the tropical Amazon basin of Brazil, 3 degrees south of the equator. Subjects were divided into three groups based on place of residence. The Amazonian urban capital city of Manaus, population 1,634,000 was classed group $1 \quad(n=89)$, with data collated from general ophthalmology clinics held at the Institute de Ophthalmology, Manaus. Smaller community held clinics in Borba and Manacapuru, which are located on Amazon River tributaries interior to Manaus (population 35,525 and 83,703 respectively) formed group $2(n=116)$. Group $3(n=20)$ comprised. of indigenous rainforest inhabitants from the Muru tribe, of uncertain population, who live by fishing and farming and were few in number as they had travelled long distances to visit relatives within Borba where they were assessed for this study.

All participants were over 20 years of age and within groups 1 and 2 selected randomly from alternating seats in the clinic waiting rooms. Data from group 3 was collected from inhabitants of alternating huts specifically accommodating visiting indigenous population. Informed consent was gained in accordance with the Declaration of Helsinki and institutional review board approval sought from The Institute of Ophthalmology, Manaus, Amazonia, Brazil. In addition to their age and place of residence (groups 1-3), the subjects were asked their current occupation. Occupation was classed as either predominantly 'indoor' (cleaners, office workers, teachers) or 'outdoor' (motorcycle taxi drivers, farmers, fishermen) and interpreted as a direct surrogate to sunlight daily exposure, with $>5$ hours/day for outdoor occupations and $<5$ hours/day for indoor occupations. Subjects were also asked about use of sunhats, sunglasses and motorcycle helmets where appropriate.

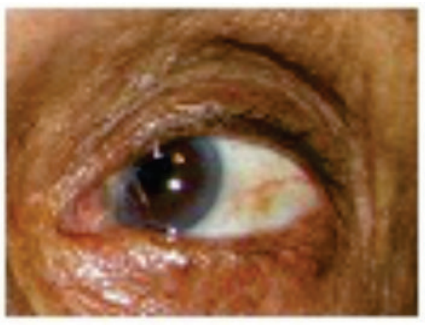

GRADE 1

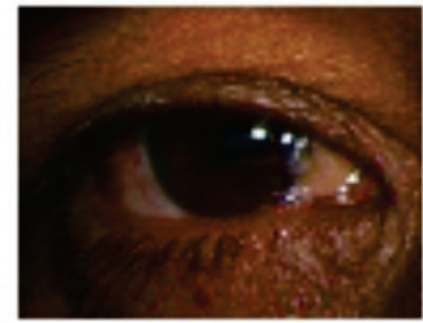

GRADE 2

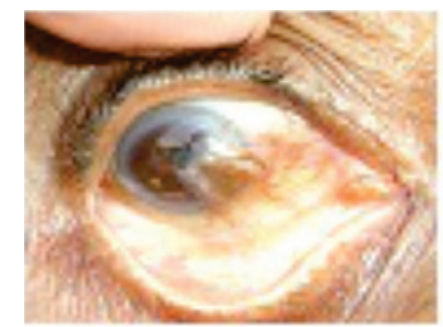

GRADE 3

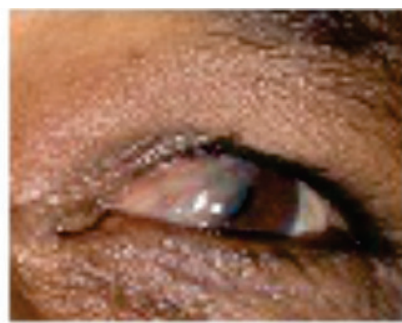

GRADE 4

Figure 1: Pterygium grading severity (1-4); a) grade 1- at the conjunctiva (to the limbus); b) grade 2 - 1-2mm across the cornea; c) grade 3 - to the pupil; d) grade 4 - half way across the pupil 
Table 1

Prevalence and percentage comparisons (\%) with $x^{2}$ analysis ( $p$ values) between pterygium and control subjects for grades 2-4 pterygia across the age groups (where: group 1- Manaus, group 2 - Manacapuru \& Borba, group 3 - Muru indigenous people) where $\mathrm{Cl}$ is estimated population $95 \%$ confidence intervals

\begin{tabular}{|c|c|c|c|c|c|c|}
\hline & & \multicolumn{2}{|c|}{$\begin{array}{l}\text { Group 1 } \\
\text { number }(\%)\end{array}$} & $\begin{array}{l}\text { Group 2 } \\
\text { number (\%) }\end{array}$ & \multicolumn{2}{|c|}{$\begin{array}{c}\text { Group } 3 \\
\text { number (\%) }\end{array}$} \\
\hline Tota & subject number & \multicolumn{2}{|c|}{89} & 116 & \multicolumn{2}{|c|}{20} \\
\hline Num & er with pterygia grade $2-4$ & \multicolumn{2}{|l|}{32} & 70 & \multicolumn{2}{|l|}{15} \\
\hline \multicolumn{2}{|c|}{ Prevalence } & \multicolumn{2}{|c|}{ 36.0 $\%$ CI 30.8- 63.6} & $\mathbf{6 2 . 5} \%$ CI 53.2- 70.9 & \multicolumn{2}{|c|}{$\mathbf{7 5 . 0} \%$ CI $53.1-88.9$} \\
\hline \multirow[t]{2}{*}{ Age } & $\begin{array}{l}21-30 \\
31-40 \\
41-50 \\
51-60\end{array}$ & $\begin{aligned} 5 & (15 \\
10 & (31 \\
7 & (21 \\
7 & (21\end{aligned}$ & & $\begin{array}{r}26(37.1) \\
4(5.7) \\
12(17.1) \\
19(27.1)\end{array}$ & $\begin{array}{l}2(13 \\
3(20 \\
3(20 \\
2(13\end{array}$ & \\
\hline & 61 above & $3 \quad(9$ & & $9(12.9)$ & \multicolumn{2}{|c|}{$5(33.3)$} \\
\hline $\begin{array}{r}\text { Subj } \\
\mathrm{M} \\
\mathrm{Fe}\end{array}$ & $\begin{array}{l}\text { ct number } \\
\text { es }(\mathrm{M}) \\
\text { hales }(\mathrm{F})\end{array}$ & $\begin{array}{c}\text { Cases Co } \\
32 \\
15(46.9) \\
17(53.1) \\
\mathbf{2 . 5 8 7}(\mathrm{p}\end{array}$ & $\begin{array}{l}\text { trols } \\
\quad 57 \\
17(30) \\
40(70) \\
=\mathbf{0 . 1 0 7 7 )}\end{array}$ & \begin{tabular}{lc}
\multicolumn{3}{c}{ Cases Controls } \\
$70 \quad 46$ \\
$53(76)$ & $30(65)$ \\
$17(24)$ & $16(34)$ \\
$\mathbf{1 . 5 0 2}(\mathbf{p}=\mathbf{0 . 2 2 0 3})$
\end{tabular} & $\begin{array}{l}\text { Cases C } \\
15 \\
4(27) \\
11(73) \\
\mathbf{1 . 6 6 7}(\end{array}$ & $\begin{array}{l}\text { ntrols } \\
5 \\
0 \\
5(100) \\
=\mathbf{0 . 1 9 6 7 )}\end{array}$ \\
\hline \multicolumn{2}{|c|}{$\begin{array}{l}<5 \text { hrs/day } \\
>5 \text { hrs/day }\end{array}$} & $\begin{array}{l}22(68.8) \\
10(31.2)\end{array}$ & $\begin{array}{l}4(94.7) \\
(5.267)\end{array}$ & $\begin{array}{rr}23(32.9) & 37(80.4) \\
47(67.1) & 9(19.6)\end{array}$ & $\begin{array}{l}1(6.7) \\
14(93.3)\end{array}$ & $\begin{array}{l}1(20) \\
4(80)\end{array}$ \\
\hline \multicolumn{2}{|c|}{$x^{2}$} & \multicolumn{2}{|c|}{$11.09(p=0.0009)$} & $25.16(p<0.0001)$ & \multicolumn{2}{|c|}{$0.74(p=0.389)$} \\
\hline
\end{tabular}

Table 2

Prevalence and percentage comparisons (\%) between pterygia and control subjects for individual grades 2, 3 and 4 in study groups 1-3 with age, gender and outdoor activity shown. $x^{2}$ analysis is recorded for each grade in correlation with over 5 hours sun exposure for the 3 groups. (groups: 1- Manaus; 2- Borba/ Manacapuru; 3- Indigenous Muru tribe)

\begin{tabular}{|c|c|c|c|}
\hline & $\begin{array}{l}\text { Group 1 } \\
\text { prevalence (\%) }\end{array}$ & $\begin{array}{c}\text { Group 2 } \\
\text { prevalence (\%) }\end{array}$ & $\begin{array}{c}\text { Group 3 } \\
\text { prevalence (\%) }\end{array}$ \\
\hline Grade 2 & $27(31) p=0.0002$ & $51(27) p=0.19$ & $10(50) p=0.5$ \\
\hline Sex Male & $10(37.0)$ & $40(78.0)$ & $3(30)$ \\
\hline Female & $17(62.9)$ & $11(22.0)$ & $7(70)$ \\
\hline Age $21-30$ & $5(18.5)$ & $29(56.9)$ & $1(10)$ \\
\hline $31-40$ & $7(25.9)$ & $2(3.9)$ & $2(20)$ \\
\hline $41-50$ & $6(22.2)$ & $9(17.6)$ & $2(20)$ \\
\hline $51-60$ & $6(22.2)$ & $14(27.5)$ & $2(20)$ \\
\hline 61 above & $3(35.5)$ & $4(7.8)$ & $3(30)$ \\
\hline Outdoor activity & Cases Controls & Cases Controls & Cases Controls \\
\hline$<5 \mathrm{hrs} /$ day & $19(70) \quad 3 \quad(5)$ & $22(43) \quad 9(20)$ & $0 \quad 4(80)$ \\
\hline$>5 \mathrm{hrs} /$ day 8 & $8(30) 54(95)$ & $29(57) 37(80)$ & $10(100) \quad 1(20)$ \\
\hline$x^{2}$ (p value) & $9.558(\mathrm{p}=0.002)$ & $14.12(p=0.0002)$ & $2.14(p=0.143)$ \\
\hline Grade 3 & $4(4.5) p<0.0001$ & $15(13.4) p<0.0001$ & $4(20) p=0.007$ \\
\hline Sex Male & $4(100)$ & $10(66.6)$ & $3(75)$ \\
\hline Female & - & $5(33.3)$ & $1(25)$ \\
\hline Age $21-30$ & - & - & $1(25)$ \\
\hline $31-40$ & $3(75)$ & $2(13.3)$ & $1(25)$ \\
\hline $41-50$ & - & $4(26.6)$ & $1(25)$ \\
\hline $51-60$ & $1(25)$ & $6(40.0)$ & - \\
\hline 61 above & - & $3(20.0)$ & $1(25)$ \\
\hline Outdoor activity & Cases Controls & Cases Controls & Cases Controls \\
\hline$<5$ hrs/day & $3(75) \quad 3(5.3)$ & $1(6.7) \quad 9(20)$ & $1(25) \quad 4(80)$ \\
\hline$>5 \mathrm{hrs} / \mathrm{day}$ & $1(25) 54(94.7)$ & $14(93.3) \quad 37(80)$ & $3(75) \quad 1(20)$ \\
\hline$x^{2}$ (p value) & $2.376(p=0.123)$ & $26.2(p<0.0001)$ & $0.032(p=0.86)$ \\
\hline Grade 4 & 1 (1.1) $p<0.0001$ & $4(3.57) p<0.0001$ & $1(5) p<0.0001$ \\
\hline Sex Male & $1(100)$ & $3(75)$ & $1(100)$ \\
\hline Female & - & $1(25)$ & - \\
\hline Age $21-30$ & - & - & - \\
\hline $31-40$ & - & - & - \\
\hline $41-50$ & $1(100)$ & $1(25)$ & - \\
\hline $51-60$ & - & $1(25)$ & - \\
\hline 61 above & - & $2(25)$ & $1(100)$ \\
\hline Outdoor activity & Cases Controls & Cases Controls & Cases Controls \\
\hline$<5$ hrs/day & $0 \quad 3(5.3)$ & $0 \quad 9(19.6)$ & $0 \quad 4(80)$ \\
\hline$>5 \mathrm{hrs} / \mathrm{day}$ & $1(100) 54(94.7)$ & $4(100) 37(80.4)$ & $1(20)$ \\
\hline
\end{tabular}


(Borba/ Manacapuru) for grade 2 at $\left.57 \%\left(x^{2}\right) 12.37 \mathrm{p}=0.0004\right)$, grade 3 at $93.3 \%\left(x^{2} 26.2 \mathrm{p}<0.0001\right)$ and grade 4 at $100 \%\left(x^{2}\right.$ $12.37 \mathrm{p}=0.0004)$. This significant relationship was also observed in group1 subjects with $>5$ hours sunlight/day and pterygia grades 2 and 3. Although group 3 showed a high prevalence of the more severe forms of pterygia, the study sample was too small for the data to be statistically significant as shown in table 2 .

\section{DisCUSSION}

To our knowledge this is the first study of pterygia within the Amazon to compare rural and urban living with patterns amongst a Brazilian population. This study was hospital based with a single person assessing all individuals by handlight to reduce bias.

Pterygium is reported to be more prevalent at tropical latitudes. ${ }^{(3)}$ Our overall prevalence of pterygia was $52 \%$ and studies in central Myanmar, of tropical climate, showed a pterygia prevalence of $19.6 \%{ }^{(8)}$. Both studies have prevalence rates greater than the $1.2 \%$ recorded within an urban Melbourne Australian temperate climate population ${ }^{(7)}$.

Our prevalence of bilateral pterygium (43\%) agrees with Jordanian studies led by Al-Bdour et al., where $44 \%$ of subjects showed bilateral eye disease ${ }^{(3)}$, but is lower than that recorded from Indonesian Archipelago studies (71.6\%). ${ }^{(9)}$ Reports by Saw et al., 1999 suggest that pterygium occurs first in the eye which is held open when facing the sun, or the dominant eye $\mathrm{e}^{(10,11)}$. The level of right and left eye disease in our study was $31 \%$ and $26 \%$ respectively.

The results show pterygia is commonest between 3150 years of age, with more severe grades noted in the elderly population of the indigenous sample and in Borba/ Manacapuru. There was no statistical relationship with age. This finding is shared by a case control study in Perth, Western Australia and highlights that intervention studies will benefit all age groups ${ }^{(12)}$.

Our study, like that by Paula et al.(13) within two indigenous Amazonian rainforest communities, showed no correlation between sex and pterygia. This is in contrast to studies led by Al- Bdour et al. within Jordan, a country where males predominantly have outdoor jobs. ${ }^{(3)}$ However within the Amazon region, outdoor occupations are not exclusively male dominated and gender is not surrogate for outdoor occupation, making gender a variable association across studies..$^{(3,14,15)}$ The Amazonian study with 624 indigenous subjects from two tribes, showed the levels of pterygia to vary from $36.6 \%$ for the group who live by river fishing to $13.7 \%$ in the second group who live by hunting within the rainforest under the sun protective forest canopy. It was suggested that the social factor of length of time spent exposed to the sun led to the prevalence difference between the two groups ${ }^{(13)}$.

A clear prevalence increase of pterygia was seen across the groups of this study. The greatest prevalence was within group 3 of the Muru tribe $(75 \%)$, where the population live a life of boat transport and self sufficient living by farming and fishing. Group 2 (Borba/ Manacapuru) with pterygia prevalence of $62.5 \%$, form communities reached by boat or airplane with limited public transport, or none in the case of Borba. Though the use of motorbike helmets is compulsory in Brazil, from observations and questionnaire within Borba, the motorbike owners rarely wore helmets, sunglasses or sun hats, especially motorbike passengers, a finding also noted in Manacapuru. In comparison, Manaus (group 1) where prevalence is at $36 \%$, has a public transport infrastructure, more indoor occupations and motorbike riders generally wear helmets as the roads are more hazardous and a fine from a traffic officer is more likely. An Australian study comparing urban and rural living showed rural levels of pterygia to be five times as high as urban residents with UVB/ sunlight as the main risk factor ${ }^{(7,8)}$. Also the Barbados Study with 4709 participants showed that outdoor workers had a pterygia level twice frequent, but the level was only one fifth if the study group always wore sunglasses outdoors ${ }^{(14)}$.

Data collected highlighted that within the Amazon there is little knowledge that pterygium is, in part, due to excessive sunlight exposure. With a high recurrence rate post surgery and with limited access to surgery in remote communities, where the majority earn the minimum wage or less, there would be significant benefit from a national Brazilian campaign to highlight pterygia and how it can be prevented or delayed in development. ${ }^{(14-17)}$ It is reported that an Australian in Perth, with 30 years sunlight exposure of 3 hours a day with no sunglasses or hat, would have a $77 \%$ lifetime reduction in sun exposure, if a hat and sunglasses were used for ten years ${ }^{(12)}$. A public health campaign would improve visual acuity, cosmesis and reduce national costs for pterygia management. Studies in 2001 showed Australia to spend yearly \$AUD 8.3 million on therapeutic and surgical intervention against pterygia ${ }^{(18)}$.

\section{Conclusion}

In conclusion pterygium has a multi-factorial pathogenesis and within this Amazonian population is of endemic proportions. This study showed pterygia to have the greatest correlation with daily exposure to sunlight, although the design was largely limited to ophthalmic clinic patients and so does not reflect a true random sample of the three studied populations. In hypothesis this may lead to an overestimation of the true prevalence of pterygium; however the patients attending ophthalmic clinics are inclusive of those seeking refraction and so reflect a wider population base. A larger representative sample for group three would be preferred however the high prevalence of pterygia in the three study group specifically in association to sunlight does highlight a clear requirement for necessary educational intervention studies. Such intervention should be aimed especially towards outdoor communities and highlight the importance of sunglasses and sunhats.

\section{Acknowledgement}

We would like to thank consultant Ophthalmologist Mr. Jacob Cohen and the Ophthalmologists Sergio Duarte, Maurício Vulcão Vasconcelos and Erica of the Institute of Ophthalmology, Manaus, Amazonia, Brazil. Also kind thanks are expressed to Borba's municipal employees Aldine Mirella de Souza e Freitas, Charute and also Andre for translation with the Muru participants. We are grateful to The Wellcome Trust and The Worshipful Company of Barbers, London for funding this research.

\section{REFERENCES}

1. Schwab L. Eye care in developing nations. 3rd ed. San Francisco: The Foundation of the American Academy of Ophthalmology; 1999. 
2. Sachsenweger R. Illustrated handbook of ophthalmology. Chicago: Wright; 1980.

3. Al-Bdour M, Al-Latayfeh MM. Risk factors for pterygium in an adult Jordanian population. Acta Ophthalmol Scand. 2004;82(1): 64-7.

4. Wong TY, Foster PJ, Johnson GJ, Seah SK, Tan DT. The prevalence and risk factors for pterygium in an adult Chinese population in Singapore: the Tanjong Pagar survey. Am J Ophthalmol. 2001;131(2):176-83.

5. Gazzard G, Saw SM, Farook M, Koh D, Widjaja D, Chia SE, et al. Pterygium in Indonesia: prevalence, severity and risk factors. $\mathrm{Br}$ J Ophthalmol. 2002;86(12):1341-6.

6. Maheshwari S. Effect of pterygium excision on pterygium induced astigmatism. Indian J Ophthalmol. 2003;51(2):187-8.

7. McCarty CA, Fu CL, Taylor HR. Epidemiology of pterygium in Victoria, Australia. Br J Ophthalmol. 2000;84(3):289-92.

8. Durkin SR, Abhary S, Newland HS, Selva D, Aung T, Casson RJ. The prevalence, severity and risk factors for pterygium in central Mynmar: the Meiktila Eye Study. Br J Ophthalmol. 2008;92(1):25-9.

9. Tan CS, Lim TH, Koh WP, Liew GC, Hoh ST, Tan CC, Au Eong KG. Epidemiology of pterygium on a tropical island in the Riau Archipelago. Eye (Lond). 2006;20(8):908-12.

10. Saw SM, Tan D. Pterygium: prevalence, demography and risk factors. Ophthalmic Epidemiol. 1999;6(3):219-28
11. Saw SM, Banerjee K, Tan D. Risk factors for the development of pterygium in Singapore: a hospital- based case-control study. Acta Ophthalmol Scand. 2000;78(2):216-20.

12. Threlfall TJ, English DR. Sun exposure and pterygium of the eye: a dose- response curve. Am J Ophthalmol. 1999;128(3):280-7.

13. Paula JS, Thorn F, Cruz AA. Prevalence of pterygium and cataract in indigenous populations of the Brazilian Amazon rain forest. Eye (Lond). 2006;20(5):533-6.

14. Luthra R, Nemesure BB, Wu SY, Xie SH, Leske MC; Barbados Eye Studies Group. Frequency and risk factors for pterygium in the Barbados Eye Study. Arch Ophthalmol. 2001;119(12): 1827-32.

15. Khoo J, Saw SM, Banerjee K, Chia SE, Tan D. Outdoor work and the risk of pterygia: a case-control study. Int Ophthalmol. 1998;22(5):293-8.

16. Solomon AS. Pterygium. Br J Ophthalmol. 2006;90(6):665-6. Comment on Br J Ophthalmol. 2006;90(6):769-72.

17. Coroneo MT, Di Girolamo N, Wakefield D. The pathogenesis of pterygia. Curr Opin Ophthalmol. 1999;10(4):282-8.

18. Wlodarczyk J, Whyte P, Cockrum P, Taylor H. Pterygium in Australia: a cost of illness study. Clin Experiment Ophthalmol. 2001;29(6):370-5. Comment in Clin Experiment Ophthalmol. 2002;30(4):312. 